\title{
SYSTEMATICS, BIOSTRATIGRAPHY AND BIOGEOGRAPHY OF FOUR FAMENNIAN SPIRIFERID BRACHIOPODS FROM MOROCCO
}

\author{
Jean-Pierre NICOLLIN ${ }^{1} \&$ Denise BRICE ${ }^{2}$
}

(8 figures)

\begin{abstract}
1 Laboratoire de Paléontologie Stratigraphique. Faculté Libre des Sciences et Institut Supérieur d'Agriculture 13 rue de Toul 59046 Lille Cedex France. UPRES-A 8014 du CNRS. e-mail jean-pierre.nicollin@fls.fupl.asso.fr

2 Laboratoire de Paléontologie Stratigraphique. Faculté Libre des Sciences 13 rue de Toul 59046 Lille Cedex France. e-mail denise.brice@fls.fupl.asso.fr
\end{abstract}

\begin{abstract}
New data on systematics, biostratigraphy and biogeography are presented in this paper. They concern four Famennian spiriferid species from South-West Morocco, discovered in Hollard's collections housed in Lille and useful for biostratigraphic and palaeobiogeographic correlations. Two of them are new : Cyrtospirifer kelbaensis n. sp., close to C. pamiricus sensu Abramian (1974, pl. 20, fig. 5, non fig. 4) not Reed, 1922 and Dichospirifer zemoulensis n. sp. close to D. cardiosinusoides (ABRAMIAN, 1957). Their systematic study is completed by a justification of their generic and specific attribution with precisions on their geographic and biostratigraphic distribution in Morocco: upper part of the Lower Famennian and lower part of the Upper Famennian (ds II - ? III sensu Hollard, 1981) for C. kelbaensis, upper part of Lower Famennian to Upper Famennian (ds II to ds V sensu Hollard, 1981) for D. zemoulensis. Two other species, recognized for the first time in Morocco, Prospira struniana (GOSSELET, 1879) and Dmitria seminoi (VERNEUIL, 1850), are compared with their type material. Their geographic and biostratigraphic distribution are stated to be in Morocco and central part of North Gondwana (North Africa and Central Asia).
\end{abstract}

KEYWORDS: brachiopods, taxonomy, Famennian, Morocco

RESUME. De nouvelles données systématiques, biostratigraphiques et biogéographiques concernant quatre espèces de Spiriférides famenniens du Sud-Ouest du Maroc, découverts dans les collections Hollard conservées à Lille et utiles pour les corrélations biostratigraphiques et paléobiogéographiques. Deux de ces espèces sont nouvelles, Cyrtospirifer kelbaensis n. sp. proche de C. pamiricus sensu Abramian (1974, pl. 20, fig. 5, non fig. 4) non Reed, 1922 et Dichospirifer zemoulensis n. sp. proche de D. cardiosinusoides (ABRAMIAN, 1957). Leur étude systématique détaillée est accompagnée d'une justification de leur attribution générique et spécifique et de précisions sur leur distribution géographique et biostratigraphique au Maroc : partie supérieure du Famennien inférieur et partie inférieure du Famennien supérieur (ds II- ? III sensu Hollard, 1981) pour C. kelbaensis, partie inférieure du Famennien supérieur à Famennien supérieur (ds II à ds V sensu Hollard, 1981) pour D. zemoulensis. Deux autres espèces, reconnues pour la première fois au Maroc, Prospira struniana (GOSSELET, 1879) et Dmitria seminoi (VERNEUIL, 1850) sont comparées à leur matériel type respectif. Leur distribution géographique et biostratigraphique est précisée au Maroc et dans la partie centrale du Nord Gondwana (Afrique du Nord, Asie Centrale).

MOTS-CLES : brachiopodes, taxonomie, Famennien, Maroc

\section{Introduction}

This paper is devoted to four Famennian spiriferid species, useful for biostratigraphic and palaeobiogeographic correlations, originating from a south-western Moroccan material (fig. 1) collected by H. Hollard and P. Jacquemont (Hollard's Collections housed in Lille). A detailed systematic study concerns two newly defined species. The first one : Cyrtospirifer kelbaensis close to C. pamiricus sensu Abramian (1974, pl. 20, fig. 5, non fig. 4), was found in the upper part of Lower Famennian and the lower part of Upper Famennian (ds II - ? III sensu Hollard 1981, fig. 2). The second one : Dichospirifer zemoulensis close to $D$. cardiosinusoides (ABRAMIAN, 1957), was found from the upper part of Lower Famennian to Upper Famennian (ds V) according to Hollard's information (fig. 2). Also documented are two other poorly preserved taxa belonging to Dmitria semino $i$ (VERNEUIL, 1850) found in the same levels as $C$. kelbaensis and Prospira struniana (GOSSELET, 1879) 


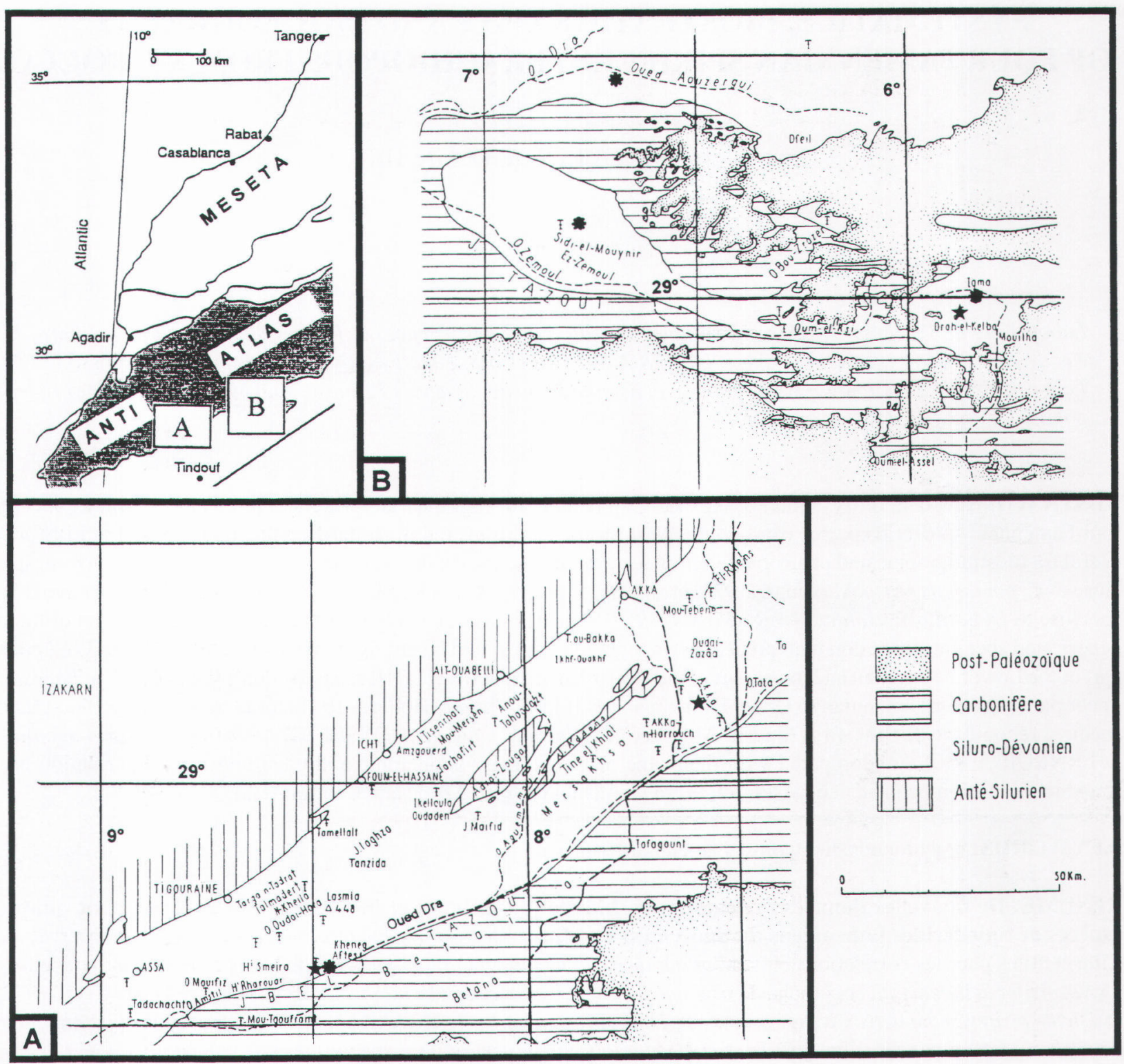

Figure 1. Location of outcrops and fossil collections after Hollard in Drot (1964, Figure 90 and 91 modified). star: location of Cyrtospirifer kelbaensis n. sp. dot: location of Dichospirifer zemoulensis n.sp.

found in Upper Famennian (ds IV to ds VI sensu Hollard 1981). For these species, the geographical and biostratigraphical distribution (fig. 1,2) are stated to be in Morocco and central part of North Gondwana (North Africa and Central Asia).

All specimens reported herein belong to Hollard's Collections and are deposited at the Faculté Libre des Sciences, Université Catholique de Lille, France (GFCL numbers).

\section{Systematics}

Superfamily Cyrtospiriferoidea Termier and Termier, 1949

Family Cyrtospiriferidae Termier and Termier, 1949
Subfamily Cyrtospiriferinae Termier and Termier, 1949 Genus Cyrtospirifer NALIVKIN in FREDERIKS, 1919 Type species : Spirifer verneuili MURCHISON, 1840 Cyrtospirifer kelbaensis n. sp.

Figs. 3.1-11, 4, 5

1964 Cyrtospirifer sp.; Drot, 1964, pl.11, fig. 10a-c.

Holotype : GFCL 3114 (i 873.18), fig. 3.1

Paratypes : GFCL 3115-3117 (i 873.1, 3, 4), GFCL 3118 (i 873.8), fig. 3.4, GFCL 3119 (i 873.17), fig. 3.5, GFCL 3120-3123 (i 873.23, 27, 34, 35), GFCL 3124 (i 873.37), fig. 3.2, GFCL 3125-3127 (Ak 89.1, 5, 10), GFCL 3128 (Ak 89.15), fig. 3.7, GFCL 3129 (Ak 89.23), fig. 3.10, GFCL 3130 (Ak 85.1), fig. 3.8, GFCL 3131 (Ak 85.3), fig. 3.9, GFCL 3132-33 (Ak 88.1, 2), GFCL 3134 (i 873.13), fig. 3.6), GFCL 3135 (i 873.32), fig. 3.3, GFCL 3136 (i 873.40), GFCL 3137 (i 873.51), fig. 3.11 . 


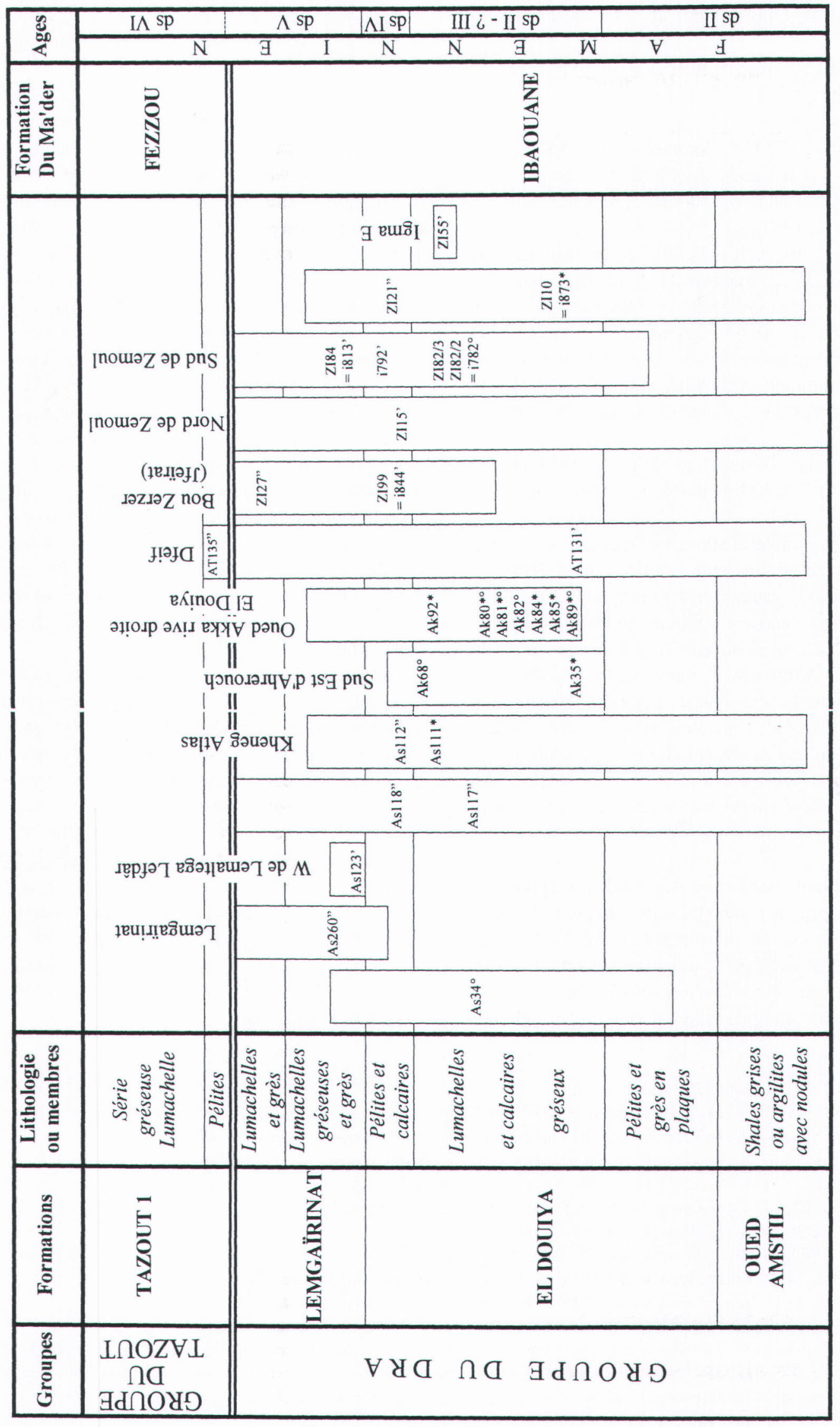

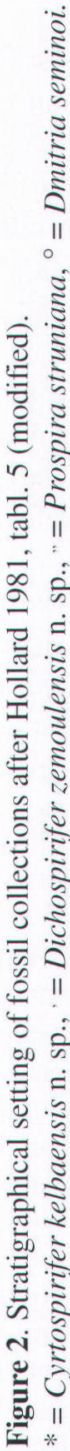


Type locality : Dra-el-Kelba anticline (fig. 1), Zemoul area, Algeria-Morocco borderline (cf. Drot, 1964)

Stratum typicum : Famennian ds II - ? III sensu Hollard 1981 (fig. 2)

Derivatio nominis : from of the name of the type locality "Dra-el-Kelba"

Type material : i 873 (14 specimens), Ak 85 (2 specimens), Ak 88 (2 specimens), Ak 89 (5 specimens.

Material : All specimens are Fammenian in age, ds II - ? III sensu Hollard, 1981

Hollard's collections, material collected by Hollard : Ak sheet Akka, Ak $35: 3$ specimens, $5 \mathrm{vv}$, right bank of Oued Akka; Ak 80 : 2 vv; Ak $81: 6$ specimens, 11 vv, 1 dv, 1 internal mould; Ak 84 : 2 specimens, 3 vv; Ak 85 : 5 vv; Ak $88: 4$ specimens, 10 vv; Ak $89: 27$ specimens, 32 vv, 1 internal mould, right bank of low Oued Akka El Douiya. As sheet Assa \& Foum-el-Hassane, As 111: 1 specimen.

Material collected by Jacquemont : South Zemoul, i 873 : 70 specimens, Dra-el-Kelba anticline, Zemoul area.

Diagnosis: Cyrtospiriferid species of medium size, with pentagonal ventral outline and rounded lateral margins, equiconvex, weakly megathyrid principally due to the presence of short mucrones. Sulcus and fold weak but well delimited. 25 to 30 simple lateral costae (in adult specimens). Micro-ornament consisting in growth-lines, capillae and spines bases. Ventral interarea subtriangular, ventrally well limited, truncated near the extremities. Delthyrium open and delthyrial chamber partially filled by callus. Delthyrial platepresnt. Dental plates short, diverging, extrasinal. Crural bases short. Interior identical to Cyrtospirifer.

Description: Shell medium sized, weakly megathyrid when the mucrones are preserved, equiconvex, wider than long. Maximal width on the hinge line, but because of the destruction of mucrones, apparently located in the posterior part of the shell, near the mid-length, by many specimens. Lateral margins rounded, drawing a slight re- entrant near the hinge line in mucronate specimens. Lateral commissures straight or weakly curved in ventral direction in the anterior part of the shell. Anterior commissure slightly uniplicate, nearly straight in young specimens.

Ventral valve : pentagonal outline. Maximal width at the hinge line. In longitudinal section, the greatest convexity occurs between the posterior one-third and the mid-length of the shell. In transverse section, the lateral slopes are regularly convex. Beak slightly curved generally not overhanging the hinge line except for gerontic specimens where it is strongly curved. Interarea of medium height (1/10 to $1 / 5$ of width, without the mucrones) subtrapezoidal, truncated towards the extremities, with sharp ventral ridges, concave, nearly catacline close to the hinge line, apsacline elsewhere. Delthyrium open, almost equilateral (angle at the top 60 to $70^{\circ}$ in average, sometimes $80-90^{\circ}$ ), delthyrial chamber partly filled by apical callus and delthyrial plate. Sulcus very shallow, sometimes obsolete, with rounded bottom, distinctly limited by two costae, always wider $(x)$, 5) than lateral costae. Tongue with rounded top, often low and prolonging the sulcus curvature, except for gerontic specimens where it is higher and distinctly curved towards the dorsal valve and thus lifting the fold up.

Dorsal valve : subtrapezoidal in outline. In longitudinal section, the greatest convexity occurs in the median part (fold area) and in the posterior one-third of the valve. The convexity decreases anteriorly in young and adult specimens, the top of fold remains horizontal in gerontic specimens. In transverse section, the lateral slopes convexity is regular. Beak slightly curved, scarcely hiding the chilidium, except for gerontic specimens where it is more strongly curved. Interarea low (1 to $2 \mathrm{~mm}$ high), with subparallel ridges, apsacline and flat, with a sharp dorsal edge. Fold low in young and adult specimens, high in the gerontic ones, well limited by a pair of grooves wider (about $\mathrm{x}$ 1,5) than lateral ones.

Figure 3. Figs 1.1-11 : Cyrtospirifer kelbaensis n. sp.

1a-e - HOLOTYPE GFCL 3114. 1a . Ventral view. 1b. Dorsal view. 1c. Anterior view. 1d. Posterior view. 1e. Lateral view.

2a-d - Paratype GFCL 3124. 2a. Ventral view. 2b. Dorsal view. 2c. Posterior view. 2d. Lateral view.

3a-d - Paratype GFCL 3135. 3a. Ventral view. 3b. Dorsal view. 3c. Posterior view. 3d. Lateral view.

4a-c - Paratype GFCL 3118. 4a. Ventral view. 4b. Anterior view. 4c. Posterior view.

5a-c - Paratype GFCL 3119. 5a. Dorsal view. 5b. Posterior view. 5c. Lateral view.

6a-b - Paratype GFCL 3134. 6a. Ventral view. 6b. Dorsal view.

7a-b - Paratype GFCL 3128. 7a. Ventral view. 7b. Posterior view.

8 - Paratype GFCL 3130 . Ventral view with ventral muscular scar and extrasinal dental plates.

9 - Paratype GFCL 3131. Ventral view with ventral muscle scars and extrasinal dental plates.

10 - Paratype GFCL 3129. Detail of micro-ornament on dorsal valve with capillae and spine basis.

11a-d - Paratype GFCL 3137. Transverse serial sections and peels. Distances are in mm from the ventral valve beak. 11 a. Section 4 $(2.5 \mathrm{~mm})$ : structure of ventral valve. $11 \mathrm{~b}$. Section $19(5.7 \mathrm{~mm})$ : structure of dorsal valve in the posterior region. $11 \mathrm{c}$. Section $22(6.1$ $\mathrm{mm}$ ): structure of dorsal valve showing crural bases and concave cardinal process with 18 lamellae. 11d. Section 28 ( $7.3 \mathrm{~mm}) \mathrm{crural}$ bases, dental sockets and extremity of tooth; $\mathrm{dp}=$ dental plates, dep = delthyrial plate, $\mathrm{cp}=$ cardinal process, uc $=$ umbonal cavities, $\mathrm{cb}=$ crural bases, $\mathrm{t}=$ tooth. 


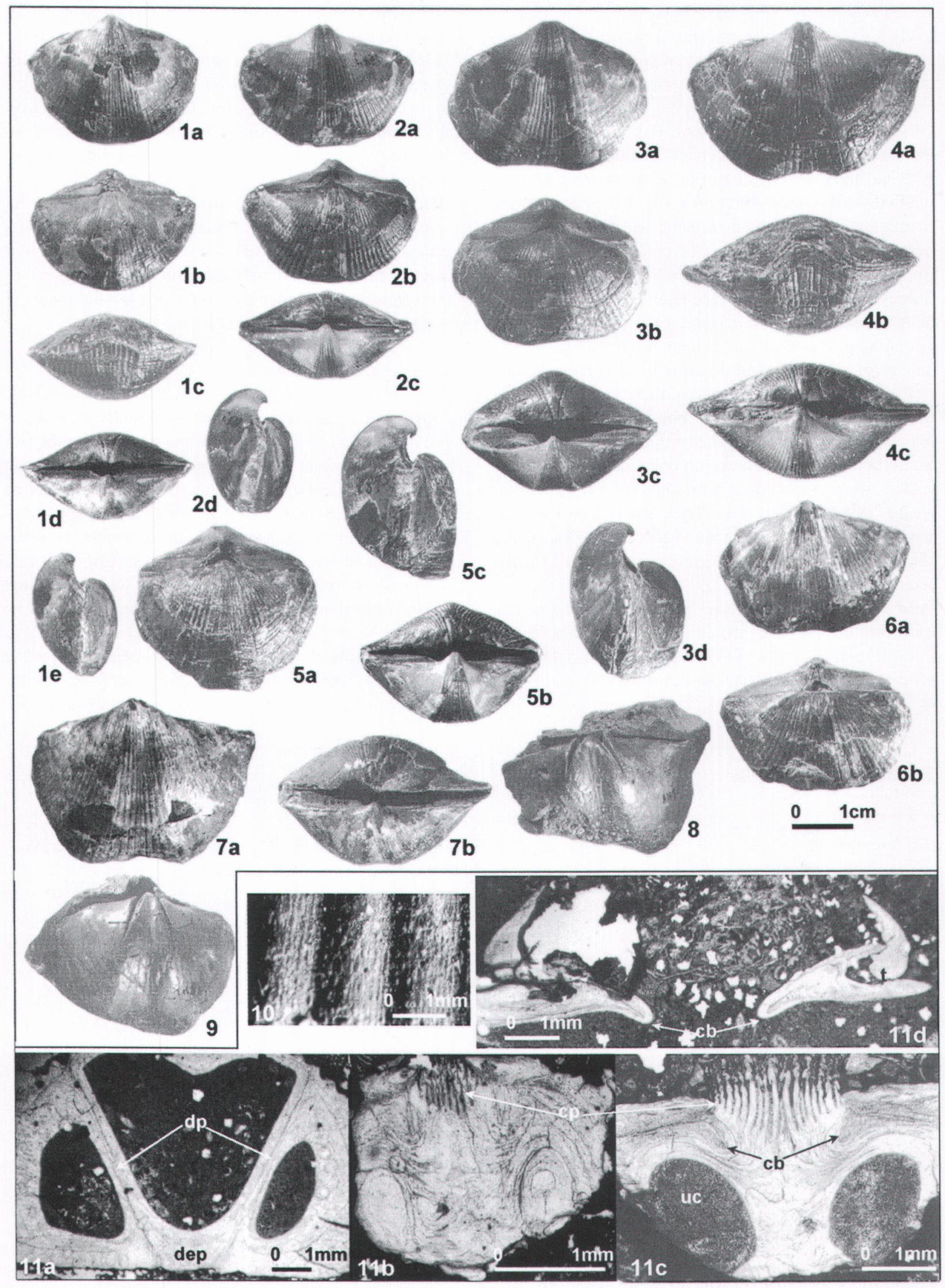


Growth variations : tongue low in young specimens, relatively high in gerontic ones. Ventral beak distinctly more curved and sulcus and fold more pronounced in the gerontic specimens.

Ornament : 25 to 30 lateral simple costae (in adult specimens and even more by someones). Costae low, rounded, widened and flattened anteriorly, regularly decreasing in width towards lateral extremities where they are narrow. Intercostal grooves about of same width as ribs in the posterior part of the shell, narrower than ribs in the anterior part.

Sulcus of Cyrtospiriferid type (fig. 4) : 10 to 13 costae near the anterior commissure. One pair of widened bounding costae. One pair of main internal costae originates from the beak and delimits three sulcus sectors. In the two more external sectors, there is generally one intercalary costa (between the bounding costae and the main internal costae) originating in the posterior part. Sometimes, this costa lacks on one side. In the central sector, one pair of costae bifurcates from the main internal costae near the beak. Then one or two more internal costae bifurcate near the median region of the shell for the first one, in the anterior one-third for the second one.

Fold of Cyrtospiriferid type (fig. 4) : 8 to 13 costae near the anterior commissure. One pair of widened bounding-fold grooves. One pair of main internal grooves originating very close to the beak which de- limits three fold sectors. In the two more external areas, there is one intercalary groove originating in the posterior region. In the central region, two pairs of grooves : the first one bifurcates from the main internal grooves at about the same level as the external bifurcation, the second one bifurcates from the previous grooves a little anteriorly. A last groove bifurcates in the anterior region.

Micro-ornament : growth lines well developed, concentric, 2 or 3 are thickened and clearly apparent in the anterior region. Capillae visible on some specimens (8 to 9 per $0,5 \mathrm{~mm}$ on the ventral valve, near the sulcus, at 15 $\mathrm{mm}$ from the apex). On some specimens, alignments of spines bases are visible (fig. 3.10 )

Internal characters (fig. 3.11)

Ventral valve : dental plates (about $1 / 3$ of the valve's length), diverging and extrasinal (externally their traces follow the first or the second lateral groove near the sulcus). Muscle scars weakly defined, spatulate, limited in its posterior part by dental plates, longitudinally striated and with radial ridges in the anterior half.

Dorsal valve : muscle scars obsolete. Myophragm sometimes present originating at some distance from the beak. Brachidium with 10 whorls. Short crural bases. Cardinal process lamellar and concave with about 22 lamellae.

Measurements of each parameter are given in tables 1-2 for the holotype and paratypes of both samples.

\begin{tabular}{|c|c|c|c|c|c|c|c|c|}
\hline $\begin{array}{l}\text { GFCL } \\
\text { Number }\end{array}$ & $\begin{array}{c}3118 \\
\text { (i } 873.8)\end{array}$ & $\begin{array}{c}3119 \\
\text { (i } 873.17)\end{array}$ & $\begin{array}{c}3114 \\
\text { (i } 873.18)\end{array}$ & $\begin{array}{c}3135 \\
\text { (i } 873.32 \text { ) }\end{array}$ & $\begin{array}{c}3122 \\
\text { (i } 873.34)\end{array}$ & $\begin{array}{c}3126 \\
(\mathrm{Ak} 89.5)\end{array}$ & $\begin{array}{c}3127 \\
(\mathrm{Ak} 89.10)\end{array}$ & $\begin{array}{c}3128 \\
(\mathrm{Ak} 89.15)\end{array}$ \\
\hline Vvl & 48.0 & $X$ & 33.5 & 43.0 & 26.5 & 49.0 & 41.0 & $X$ \\
\hline $\mathrm{L}$ & 29.4 & 27.0 & 22.3 & 27.8 & 20.4 & 31.5 & 27.6 & 31.2 \\
\hline W & 42.8 & 33.0 & 30.8 & 35.5 & X & 34.4 & 32.8 & 40.0 \\
\hline Dvl & 23.9 & 22.9 & 18.3 & 19.3 & 17.3 & 23.9 & 20.2 & 25.3 \\
\hline $\mathrm{T}$ & 21.1 & 20.7 & 15.9 & 21.2 & 13.5 & 23.4 & X & X \\
\hline $\mathrm{Ah}$ & 04.2 & 05.8 & 04.9 & 05.8 & 03.7 & 06.6 & 06.4 & 05.5 \\
\hline Sw & 15.0 & 14.3 & 12.8 & 15.8 & 09.0 & 14.5 & 14.1 & 18.0 \\
\hline $\mathrm{Sa}$ & 24 & 23 & 28 & 25 & 23 & 25 & 28 & 23 \\
\hline $\mathrm{Fa}$ & 24 & 27 & 26 & 31 & 25 & $X$ & 28 & 23 \\
\hline $\mathrm{Da}$ & $\mathrm{X}$ & 90 & 80 & 66 & 72 & 77 & 62 & 63 \\
\hline $\mathrm{Aa}$ & 126 & 119 & 120 & 115 & 120 & 116 & 116 & 115 \\
\hline Vnc & 23 & X & 21 & 21 & $>20$ & 24 & 28 & $>30$ \\
\hline Dnc & 28 & 21 & 24 & $>24$ & $>20$ & $>18$ & 28 & $>30$ \\
\hline Snc & 11 & $X$ & 12 & 10 & 10 & 10 & 13 & 11 \\
\hline Fnc & 10 & 12 & 10 & 12 & 8 & $X$ & X & 10 \\
\hline
\end{tabular}

Table 1. Cyrtospirifer kelbaensis $\mathrm{n}$. sp. Comparison between populations originating from different samples.

In Hollard and Jacquemont's material, numerous specimens of $C$. kelbaensis were collected in two samples : i 873 (Dra-el-Kelba anticline, 70 specimens) and Ak 89 (right bank of low Oued Akka, 27 specimens). We have measured different parameters on each specimen of both samples when it was possible. The measured parameters are as follows (fig. 5) : length $=\mathrm{L}$, ventral valve length $=\mathrm{Vvl}$, width $=\mathrm{W}$, dorsal valve length $=\mathrm{Dvl}$, thickness $=\mathrm{T}$, area height $=\mathrm{Ah}$, sulcus width $=\mathrm{Sw}$, apical angle $=$ Aa, delthyrium angle $=\mathrm{Da}$, sulcus and fold angles $=\mathrm{Sa}, \mathrm{Fa}$, number of costae on ventral lateral slopes $=\mathrm{Vnc}$, dorsal lateral slopes $=$ Dnc, sulcus $=$ Snc and fold = Fnc. 


\begin{tabular}{|lccccc|}
\hline & $\begin{array}{c}\text { i } 873 \text { sample } \\
\text { (means) }\end{array}$ & $\begin{array}{c}\text { i } 873 \text { sample } \\
\text { (variance) }\end{array}$ & $\begin{array}{c}\text { Ak 89 sample } \\
\text { (means) }\end{array}$ & $\begin{array}{c}\text { Ak 89 sample } \\
\text { (variance) }\end{array}$ & $\begin{array}{c}\text { Comparison of means } \\
\text { (t-test) }\end{array}$ \\
\hline Vvl & 42,13 & 30,78 & 41,9 & 18,4 & equality \\
L & 27,33 & 8,22 & 28,29 & 4,61 & equality \\
W & 35,86 & 12,18 & 32,34 & 9,53 & inequality \\
Dvh & 21,48 & 5,05 & 22,14 & 4,44 & equality \\
Ah & 5,55 & 1,02 & 5,45 & 1,26 & equality \\
Sw & 13,96 & 3,29 & 14,23 & 3,56 & equality \\
Sa & 24,46 & 2,84 & 22,45 & 2,05 & inequality \\
Fa & 26,43 & 6,53 & 22,8 & 3,29 & inequality \\
Da & 66,34 & 79,23 & 65,35 & 62,81 & equality \\
Aa & 120,98 & 26,59 & 116,24 & 45,93 & inequality \\
Vnc & 24,05 & 6,16 & 25,07 & 9,30 & equality \\
Dnc & 24,25 & 5,4 & 25,57 & 9,62 & equality \\
Snc & 11,38 & 0,94 & 11,62 & 1,42 & equality \\
Fnc & 10,21 & 1,51 & 10,55 & 1,27 & equality \\
\hline
\end{tabular}

Table 2. Cyrtospirifer kelbaensis n. sp. Comparison of two populations of samples i 873 and Ak 89 by a statistical study using t-test (Dagnelie, 1998), which is a good tool for comparing means of all measured parameters (legend on Table 1). Some differences between the populations are highlighted.

Ak 89 specimens are more globular than i 873 ones with a smaller width. That means that the i 873 specimens are a little more elongated.

The consequence is that for Ak 89 specimens, the apical angle is weaker $\left(116\right.$ vs $\left.121^{\circ}\right)$ as well as the sulcus $\left(22\right.$ vs $\left.24^{\circ}\right)$ and fold $(23$ vs $26^{\circ}$ ) angles. These few significant differences can't be regarded as evolution trends because of the small number of Ak 89 specimens .

Discussion : The species C. kelbaensis shows the external and internal characters of the genus Cyrtospirifer: transversally elongate shape with costate sulcus and fold, simple lateral costae, bifurcated on sulcus and fold, presence of delthyrial plate and dental plates, hinge line not denticulate. Its ornament is also characteristic for the genus, specially the sulcus and fold ornament and micro-ornament with spines, capillae and growth-lines.

The genus Dmitria has also a very weakly developed sulcus and fold (often obsolete or absent) like in $C$. kelbaensis but differs from the latter in being more inflated, with a larger size, a weakly brachythyrid shape and its lateral costae are wide and flat with very narrow intercostal grooves. By its weakly developed sulcus and fold and numerous lateral costae, this equiconvex species, when incomplete, may be confused with young incomplete specimens of Dmitria seminoi. On the contrary, the adults of $D$. seminoi sharply differ by their brachythyridy, their higher length vs width ratio and their ornament consisting of anteriorly very flattened costae with a tendency to the dichotomy.

C. kelbaensis also bears some external resemblances with the type species of the genus Enchondrospirifer, E. ghorensis, by its obsolete fold. However, E. ghorensis is a brachythyrid species and its sulcus is more differenciated but badly delimited. Moreover there are internal differences : presence in E. ghorensis 1) of numerous "pustules" on the internal surface of the test valves which gives a granular aspect, 2) of short subparallel dorsal apical lamellae.

C. kelbaensis is a separate species, different from the other species of Cyrtospirifer by the following features : pentagonal ventral outline, weakly megathyrid, with chiefly weakly developed sulcus and fold, micro-ornament partly made of capillae and ventral interarea truncated in the extremities.

Among Cyrtospirifer species, C. pamiricus sensu Abramian seems to be the closest. But, the pamiricus species, erected by Reed (1922), is problematic because the illustrations given by the author for the Pamir material concern different species figured under the name $C$. pamiricus. Among the Armenian specimens attributed to C. pamiricus, figured by Abramian (1974, pl. 20, fig. 5, non fig. 4) one resembles $C$. kelbaensis. However, it slightly differs by a more quadrangular outline and a sharper delthyrium angle.

C. leboeufensis GREINER, 1957 is also relatively close to C. kelbaensis by its external outline and rather obsolete sulcus and fold. Nevertheless, in leboeufensis, the sulcus is poorly delimited, costae weakly marked and above all, dental plates are longer, subparallel and converging.

The general shape of $C$. semisbugensis NALIVKIN, 1937 is reminiscent of C. kelbaensis but the former has a deeper and narrower sulcus, a higher fold, more numerous lateral costae and longer parallel dental plates.

The type species of the genus, $C$. verneuili (MURCHISON, 1840), is easily distinguished from $C$. 


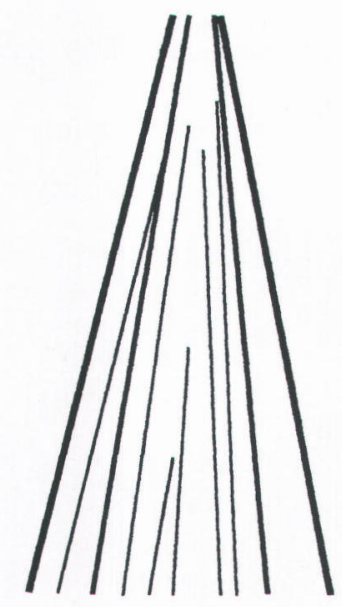

GFCL 3135

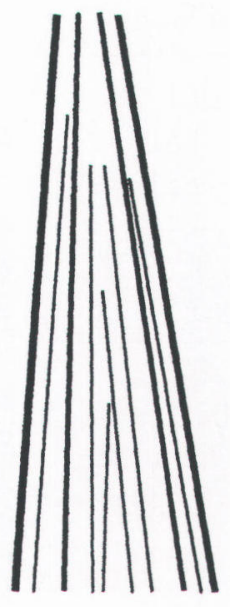

GFCL 3124

Sulcus ornamentation

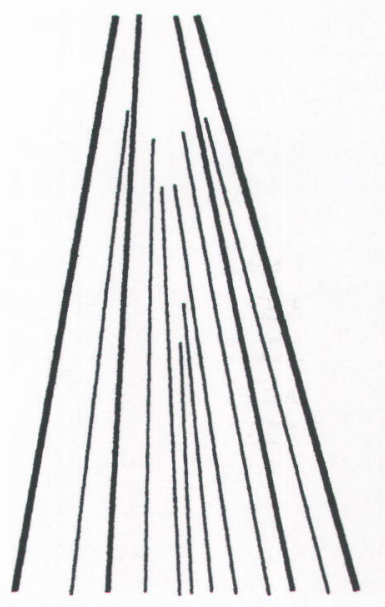

GFCL 3135

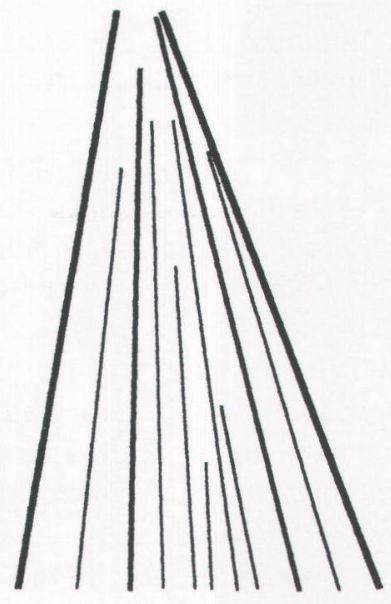

GFCL 3123

Fold ornamentation

Figure 4. Detail of ornamentation on sulcus and fold of some specimens of Cyrtospirifer kelbaensis n. sp.

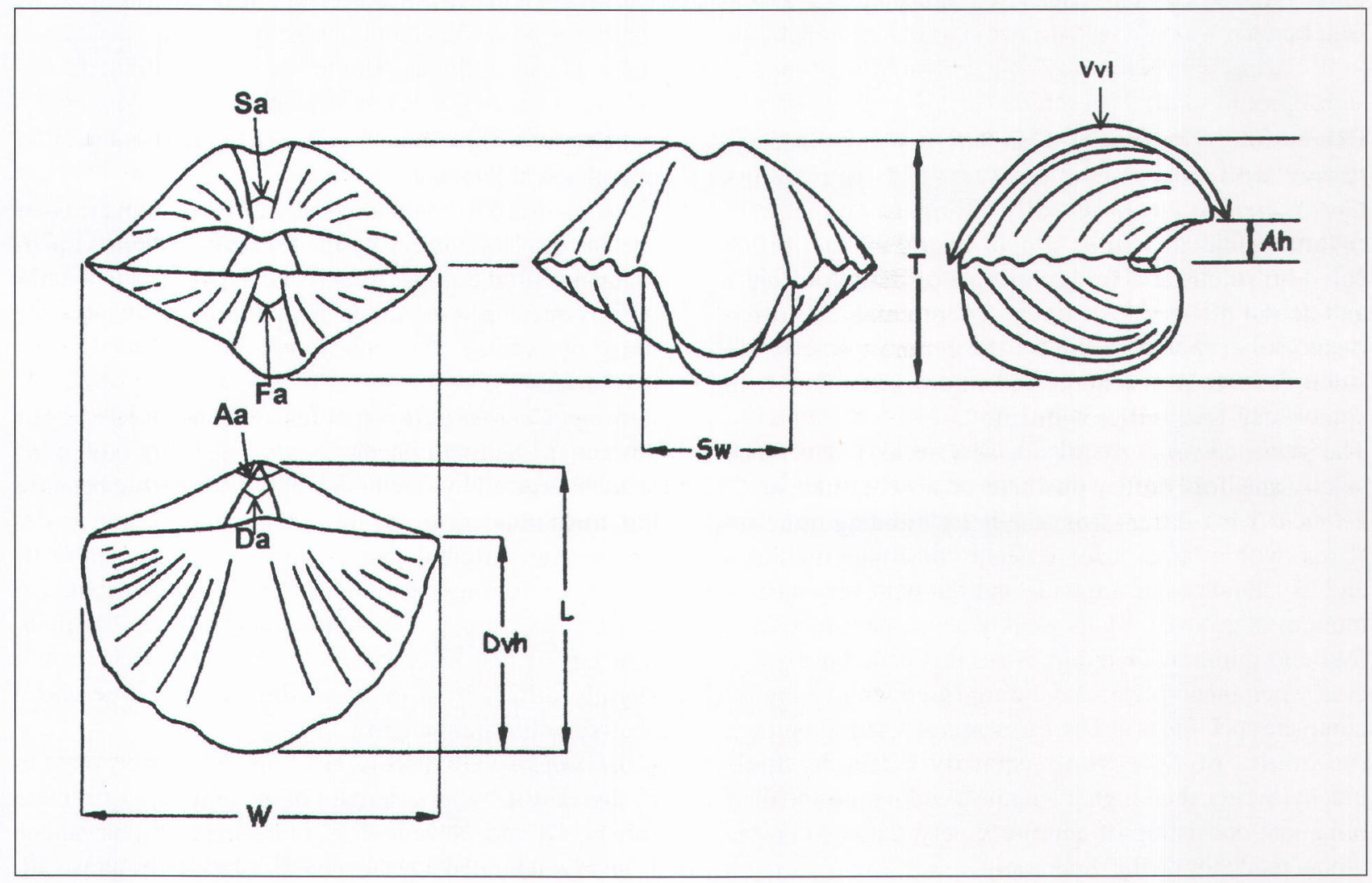

Figure 5. Some parameters measured on Cyrtospirifer kelbaensis n. sp. specimens (after Gourvennec, 1989, Figure 18, modified). 
kelbaensis by a more transversally elongate outline, a deep and narrow sulcus and a prominent and narrow fold which both have more numerous dichotomous costae ( 15 to 20 in the anterior region vs 8 to 14).

Two species of Cyrtospirifer are often quoted by the Russian authors to characterize the lower Famennian of the East European platform : C. asiaticus BRICE, 1971 $(=C$. archiaci MURCHISON, VERNEUIL, KEYSERLING, 1845 non MURCHISON, 1840) and $C$. sulcifer sensu NALIVKIN, 1937 (non HALL \& CLARKE, 1894) which must be re-defined. C. asiaticus differs from $C$. kelbaensis mainly by the following characters : deeper sulcus, longer (one half of the shell vs one third) and subsinal becoming intrasinal dental plates, sharper angle of delthyrium ( $40^{\circ}$ vs $65^{\circ}$ in average), smaller size, high ventral area. C. sulcifer sensu NALIVKIN, 1937 is a very transverse species with sulcus and fold more developed than in C. kelbaensis and a ventral beak overhanging the hinge line.

Subfamily Cyrtiopsinae? Ivanova, 1972

Genus Dmitria SIDIACHENKO, 1961

Type species : Dmitria romanovskii (NALIVKIN, 1930)

Dmitria seminoi (VERNEUIL in VISQUENEL, 1850)

Figs 6.1-8, 8.8

1850 - Spirifer Seminoi nov. sp.; Verneuil in Visquenel, p. 501.

1967 - Dmitria seminoi (VERNEUIL, 1850); Vandercammen, p. 4-14, pl. 1, fig. 1-11, pl. 2, fig. 1-16, pl. 3, fig. 1-7, pl. 4, fig. 8, fig-texte 3-6.

Synonymy cf. Brice 1971, p. 163.

Age : Famennian (ds II - ? III sensu Hollard 1981).

Material : All specimens are Famennian in age, ds II - ? III sensu Hollard, 1981.

Hollard's collections, material collected by Hollard : As sheet Assa \& Foum-el-Hassane, As 34 : 2 vv oued Amstil ; Ak sheet Akka, right bank of oued Akka El Douiya Ak $68: 2 \mathrm{vv}, 1 \mathrm{dv}$; Ak 80 : 1 specimen, $1 \mathrm{vv}$; Ak : 81, $1 \mathrm{vv;}$ Ak 82 : 1 vv; Ak 88: 3 specimens, 2 vv; Ak 89: 6 incomplete specimens, $1 \mathrm{vv}$; Ak 92 : $1 \mathrm{vv}$.

Material collected by Jacquemont: South Zemoul i 782 : 1 specimen, $1 \mathrm{dv}$.

Discussion: The Moroccan material is not adequate and too badly preserved to give a description of this species. However, these specimens belong to Dmitria seminoi by the following features : length and width almost equal, form biconvex, shell equivalve and weakly brachythyrid; sulcus and fold obsolete or absent; ventral interarea apsacline, weakly concave ventrally limited by ridges originating at the beak, delthyrium open, lateral costae simple (26-30) with intercostal grooves of the same width and rounded in posterior region, anteriorly becoming wide, flat with narrow intercostal grooves, median costae divided. Delicate spine bases (fig. 8.8); dental plates divergent extrasinal, delthyrial plate developed, hinge line not denticulate.
All specimens are smaller than the adult specimens of D. seminoi (type material). As for young specimens, they are weakly brachythyrid and have less numerous lateral costae.

\section{Biogeography and biostratigraphy in central part of the North Gondwana}

The type material studied by Verneuil (1845) was collected by H. de Hell in Iran (Elburz). Brice (Brice et al., 1974) found it in the Famennian material collected by de Lapparent from Robat-e-Garabil (Eastern Elburz). The species was also found in Caucasus (Abich, 1858) and described by Abramian (1957) in South West Armenia (Transcaucasia). Rzhonsnitskaia (1988, p. 264-265) includes the southern Transcaucasian species in the marginifera Zone which corresponds to the upper part of Lower Famennian and the lower part of Upper Famennian. In South-Western Morocco, D. semino $i$ was found in the upper part of Lower Famennian (ds II - ? ds III sensu Hollard, 1981). In Afghanistan, D. seminoi is abundant in the same levels, in the Axial Zone, particularly at Robat-e-Paï, Ghouk, Iraq near Bamian and Hajigak (Brice, 1971, 1977, p. 272). Its presence in the Famennian of Spain (Garcia-Alcalde \& MenendezAlvarez, 1988, p. 25) and Algeria (Legrand, 1968, tab. 6, p. 280-281) needs to be confirmed.

Genus Dichospirifer BRICE, 1971

Type species : Dichospirifer thylakistoides BRICE, 1971 Dichospirifer zemoulensis n. sp.

Figs 6.9-10, 7.

Holotype : GFCL 3106 (AT 131.1), fig. 6.9a-e, fig. 7.8 Paratypes : GFCL 3107 (AT 131.2), fig. 6.10, GFCL 3108 (AT. 131.4), fig. 7.1, GFCL 3109 (AT 131.6), GFCL 3110 (AT 131.8), fig. 7.2, GFCL 3111 (AT 131.10), GFCL 3112 (AT 131.13), fig. 7.3., GFCL 3113 (i 792.1), figs.7.5, 7.6, GFCL 4644 (AT 131.5), fig.7.4, GFCL 4645 (i 792.2), fig. 7.7.

Type locality : Morocco, Agadir-Tissint, plain of Dfeil, below the Hamada (Drot, 1964, fig. 91)

Stratum typicum : Famennian (ds II- ?III sensu Hollard 1981)

Derivatio nominis : from Oued Zemoul area

Age : Famennian ds II - ? III sensu Hollard 1981 to Famennian ds V

Material : Hollard's collections, material collected by Hollard: As sheet Assa \& Foum-el-Hassane, Jbel Tazout, As 111: 7 vv, Famennian ds II - ? III sensu Hollard 1981; As 123: 1 specimen, 1 vv base of Famennian ds V. AT sheet Tata, Plain of Dfeil, AT 131: 3 specimens, 12 vv Famennian ds II - ? III sensu Hollard 1981. Zl sheet Oued Zemoul, Zl 55 : 4 vv Igma Famennian top of ds II - ? III sensu Hollard 1981, Zl 15 : 1 vv North Zemoul Famennian base of ds IV.

Material collected by Jacquemont : i 792 : 2 specimens, 6 vv South Zemoul Famennian ds IV; i $844=$ Zl $99: 3$ 
vv Bou Zerzer Famennian ds IV; i $813=$ Zl $84: 2$ vv South Zemoul Famennian ds V; i $783=$ Zl 88 : ? 1 dv North of the Zemoul anticline, according to Hollard's ambiguous level Famennian ds II or Tournaisian.

Diagnosis: Large-sized for the genus, moderately to strongly dorsibiconvex, sub-trapezoidal rounded outline, wider than long, maximum width near the mid-length, weakly brachythyrid with short mucrones. Subtrapezoidal ventral interarea, slightly concave, delthyrium open. Rounded fold and sulcus, often not clearly delimited from flanks for the latter, strongly developed in anterior region in gerontic forms. Numerous thin costae, most of them bifurcating mainly on posterior region, crossed by thin growth lines. Hinge line not denticulate. Long dental plates in ventral valve, weakly divergent posteriorly, then becoming supararallel recurving towards the midline anteriorly, enclosing muscle field. In dorsal valve crural bases embedded in apical callus.

Description: Ventral valve moderately inflated, most convex in umbonal region. Beak curved not overhanging hinge line. Apsacline, weakly concave, sub-trapezoidal interarea, truncated near the extremities, defined by beak ridges almost parallel to hinge line, vertically striated. Sulcus originating at the apex as narrow groove, becoming wider and deep anteriorly, producing a broadly V- or $\mathrm{U}$-shaped profile and a spatulate tongue (Table 3).

Dorsal valve triangular in transverse section and gibbous umbonal region. Beak curved above hinge line. Interarea low, defined by angular ridges parallel to hinge line, orthocline or slightly apsacline. Fold originating at beak, poorly defined by bounding grooves deeper than intercostal grooves.

\begin{tabular}{|llll|}
\hline GFCL & Holotype 3106 & Paratype 3107 & Paratype 3113 \\
\hline L & 35.3 & 31.8 & 30.4 \\
W & 49.8 & 44.7 & 40.5 \\
Hl & 47.6 & 43.8 & 35 \\
T & 38.3 & 32.8 & 31.5 \\
Sw & 18.7 & - & 18.5 \\
\hline
\end{tabular}

Table 3. Dichospirifer zemoulensis n. sp. Measurements (in mm). Abbreviations : L = length; $\mathrm{W}=$ width; $\mathrm{Hl}=$ hinge line; $\mathrm{T}=$ thickness; Sw sulcus width.

Figure 6. Figs 6. 1-8: Dmitria seminoi (VERNEUIL, 1850)

1 - GFCL 3138. Ventral view.

2 - GFCL 3139. Ventral view.

3a-b - GFCL 3140. Ventral and posterior views.

$4 a-b-$ GFCL 3141. Ventral and posterior views.

5a-b - GFCL 3142. Ventral and posterior views.

6 - GFCL 3143. Ventral view.

7 - GFCL 3144. Ventral view.

8a-b - GFCL 3145. Transverse serial sections and peels, a : peel $7(2.1 \mathrm{~mm})$; $\mathrm{b}$ : peel $18(4.8 \mathrm{~mm})$. Distances are in $\mathrm{mm}$ from the ventral valve beak. Abbreviations as on Figure 3.11.

Figs 6.9-10: Dichospirifer zemoulensis n. sp.

9a-e. Holotype GFCL 3106. Ventral, dorsal, lateral, posterior, anterior views.

10a-b. Paratype GFCL 3107. Posterior and ventral views of a young specimen. 


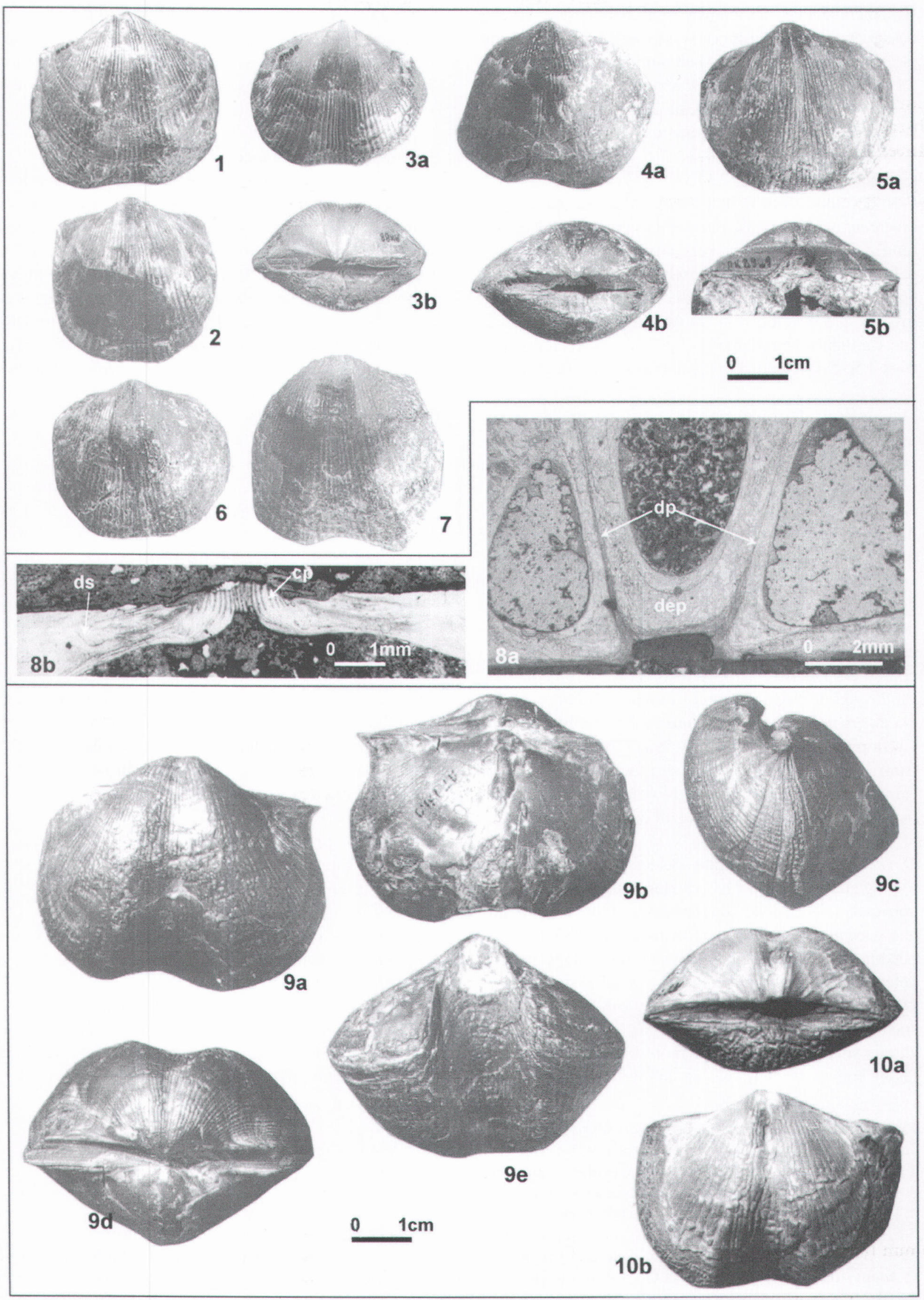


Ornament: Valves covered by numerous costae. Lateral costae and intercostal grooves are similar in width, simple, rounded near the beak, their number varies from 15 to 19 before the first dichotomy. Most of lateral costae and median ones generally bifurcate in the posterior region. All costae are crossed by numerous fine growth lines.

Internal characters (fig. 7.5)

Well developed long dental plates, extrasinal and weakly divergent near the beak, intrasinal in the umbonal region tending to bend in brackets anteriorly; rudimentary delthyrial plate near the beak where it is embedded in an apical callosity. Ventral umbonal cavities open. Ventral myophragm developed in front. Hinge line not denticulate. Cardinal process lamellar (fig. 7.5d). Short crural bases (figs $7.5 \mathrm{c}$-d) embedded in the dorsal apical callosity.

Discussion: This species is included in the genus Dichospirifer BRICE, 1971 on the basis of the following characters : shape strongly dorsibiconvex, brachythyrid and weakly mucronate; sulcus narrow posteriorly, widened and poory defined anteriorly; obsolete fold, better defined anteriorly; valves covered with numerous fine costae all divided by dichotomy, crossed by numerous and fine growth striae; spines absent*. Hinge line not denticulate, dental plates extrasinal, rudimentary delthyrial plate, ventral myophragm, short crural bases embedded in the apical dorsal callosity* (fig. 7.5d). The characters marked with an asterisk were clarified by Plodowski in Plodowski and Kononova (1994).

Dichospirifer, Dmitria, Eodmitria are included in the Cyrtiopsinae by Carter et al. (1994). They mainly differ from Cyrtiopsis and other genera included in this subfamily by poorly limited ventral sulcus and pseudodeltidium lacking or small deltidial plates.

D. zemoulensis is a separate species because of the following characteristics : its very large size, the important convexity of the valves and the height of the fold in adults and gerontic forms, its long dental plates which tend to become intrasinal in the umbonal region and which bend anteriorly towards the median line in some specimens.

D. cardiosinusoides (ABRAMIAN, 1957) is the closest species. It can be distinguished easily, however by its slighly smaller size, its shape more widened in front, the lesser convexity of flanks, its higher and less concave ventral interarea, its deep angular sulcus anteriorly very widened and its fold with a median furrow. The distinction with the other known species is easier because they are generally smaller and have a shallow sulcus and a fold poorly delimited anteriorly.

\section{Dichospirifer biogeography}

The genus Dichospirifer has a wide geographic distribution but it is restricted to the Famennian (upper part of Lower Famennian to Upper Famennian). It is represented by six species : Dichospirifer thylakistoides BRICE, 1971, D. piriformis BRICE, 1971, from the Axial Zone in Afghanistan and Eastern Elburz in Iran (Brice in Brice et al., 1978), D. velbertensis PLODOWSKI, 1994, from the Rhenish Slate Mountains, D. anatolicus PLODOWSKI, 1994, from Anatolia in Turkey, D. cardiosinusoides (ABRAMIAN, 1957) from Armenia in Transcaucasus and Eastern Elburz (Iran) because D. aff. D. thylakistoides (Brice in Brice et al., 1974, p. 211, pl. 24, fig. 10) belongs to $D$. cardiosinusoides, and $D$. zemoulensis from Morocco in North Africa. Moreover, there are some species not yet defined : Dichospirifer sp. indet. cited by Plodowski (Plodowski \& Kononova, 1994, p. 19) from Cornwall in Great Britain; D. feliksi GRETCHISHNIKOVA, nomen nudum, in the southern Transcaucasus (Rzhonsnitskaia \& Mamedov, 1988, p. 131), Dichospirifer cited and figured by Brice (1971, p. 201 , p. 12 , fig. 6) from Ghouk and probably in the northern part of Central Mountains in Afghanistan (Brice in Mistiaen, 1985, p. 47, 52). The genus is also present in the Tabas area (Eastern Iran) where one large specimen (loose sample) was collected by P. Sartenaer from the Famennian of the Howz-e-Dorah section (IGCP 421 meeting, field trip December 1998).

Superfamily Spiriferoidea King, 1846

Family Spiriferidae King, 1846

Subfamily Prospirinae Carter, 1974

Genus Prospira MAXWELL, 1954

Type species: Prospira typa MAXWELL, 1954

Prospira struniana (GOSSELET, 1879)

Figs 8.1-5, 7, 9-12

1879 - Spirifer strunianus nov. sp.; Gosselet, p. 398.

1879 - Spirifer strunianus var. alatus; Gosselet, p. 398.

non 1880 - Spirifer strunianus; Gosselet, pl. 5, fig. 2, 2a (fig. 3 = Tylothyris laminata)

Figure 7. Figs 7. 1-8 : Dichospirifer zemoulensis n. sp.

1a-b. Paratype GFCL 3108. Ventral valve, a: exterior view, b: interior view showing long dental plates bent anteriorly and myophragm. 2 a-b. Paratype GFCL GFCL 3110 . Ventral valve, a: exterior view, b: interior view.

3. Paratype GFCL 3112. Ventral valve, exterior view.

4. Paratype GFCL 4644. Ventral valve, interior view.

5-6. Paratype GFCL 3113. 5a-d. Transverse serial sections and peels. Distances are in $\mathrm{mm}$ from the ventral valve beak. 5a-b. Sections $4(3.05 \mathrm{~mm})$ and $18(8 \mathrm{~mm})$ structure of ventral valve. $5 \mathrm{c}$. Section $15(6.8 \mathrm{~mm})$ : dental socket and tooth. $5 \mathrm{~d}$. Section 12 $(5.4 \mathrm{~mm})$ structure of dorsal valve in the posterior region, dep $=$ delthyrial plate, $\mathrm{cp}=$ cardinal process, $\mathrm{cb}=$ rural bases, $\mathrm{t}=$ tooth; 6 a-e: dorsal, ventral, posterior, anterior, lateral views. Abbreviations as on Figure 3.11.

7. GFCL 4645, exfoliated specimen showing the tracks of dental plates.

8. Holotype GFCL 3106 showing divided lateral costae. 


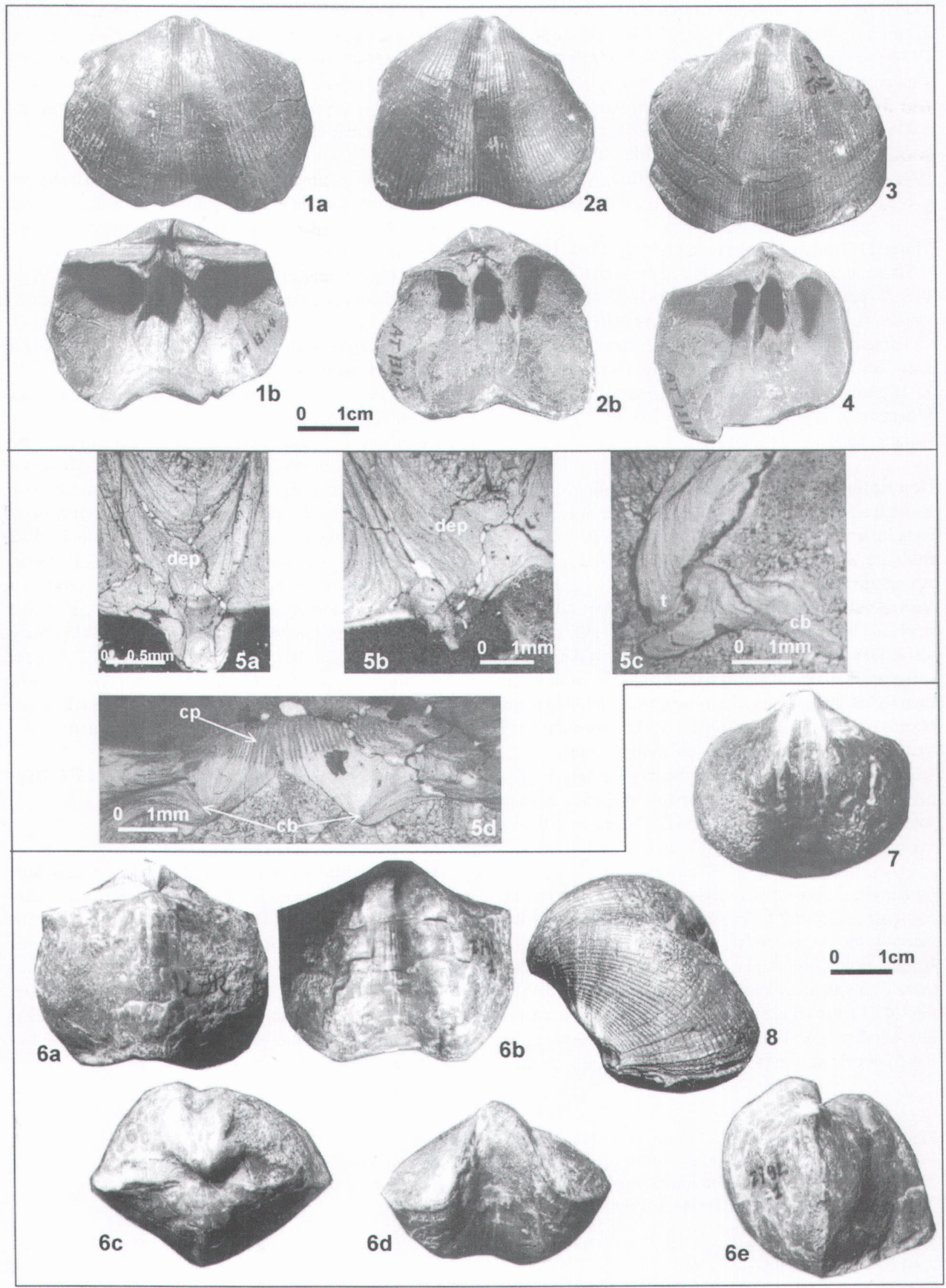


1929 - Spirifer strunianus GOSSELET; Dehée, p. 21 22, pl. 3 fig. 4-11.

1956 - Spinocyrtia struniana (GOSSELET); Vandercammen, p. 1-9, pl. 1, 3, fig.-texte.

p.p. 1971 - Eobrachythyris strunianus strunianus (GOSSELET); Brice, p. 186-190, pl. 13, fig. 4-6, fig.texte 44-45 (non 3GK 000 157, p. 188 = Prospira sp.) 1997 - Prospira struniana (GOSSELET, 1879); Brice, p. 67-73, fig. 1, pl. 1, fig. 1-6.

Material : Hollard's collections : As sheet Assa \& Foumel-Hassane, Jbel Tazout, As 112:1 vv, As 117: $1 \mathrm{vv}$; As 118: 2 specimens, 1 vv Famennian ds IV; As $260: 3 \mathrm{vv}$ Famennian ds V. AT sheet Tata, Plain of Dfeil, AT 135: 1 vv Famennian ds VI. Zl sheet oued Zemoul, Zl 21 : 4 vv, $1 \mathrm{dv}$ North of anticline Dra-el-Kelba Famennian ds IV, Zl 27 : 1 dv Bou-Zrazer, Famennian ds V.

Morzadec's collections : Jbel Tazout : $2 \mathrm{vv}, 1 \mathrm{dv}$ Famennian V.

Description : Moroccan specimens megathyrid, always wider than long with angular lateral extremities, moderately inflated and equivalve. Narrow, obsolete sulcus and fold, limited by a pair of wide costae for the sulcus and strong grooves for the fold.

Ventral valve more convex in the median part, small ventral beak, weakly curved above the low, weakly concave, apsacline interarea, that is limited by sharply defined and sub-parallel beak ridges and ornamented by vertical and transversal striae. Delthyrium open, small deltidial plates. Narrow, rounded ventral sulcus, well defined along the valve by a pair of wide sulcus-bounding costae.

Dorsal valve more convex in the median region. Fold originating from the inconspicuous beak, narrow, rounded, obsolete but well defined by strong fold-bounding grooves.

Ornament: Simple and rounded dorsal and ventral lateral costae (15 to 20 ) becoming progressively obsolete laterally. Valves covered by thin numerous radial capillae similar to that of the type species, crossed by fine, concentric growth lines. Ventral sulcus with one median simple sulcal costa (figs 8. 1a, 2a, 7, 11, 12) with, occasionally, another lateral sulcal costa starting posteriorly (figs 8.4-5) or originating from the sulcus-bounding costae in the anterior part of the shell. Dorsal fold ornamented by a median groove (figs $8.2 b-10$ ) or by one median and two lateral grooves (fig. 8.3a) originating from foldbounding grooves.

Hinge line denticulate. Dental plates short and divergent, umbonal cavities filled by callus.

Discussion: Moroccan specimens are rare and badly preserved, some of them are slightly smaller than the type specimens, but all show the external and internal features of $P$. struniana.

Age : Famennian (ds IV to VI sensu Hollard 1981, fig. 2 and written communication from unpublished notes).

\section{Biogeography and biostratigraphy in central part of} the North Gondwana

The type material originates from the Upper Famennian (Strunian) of Avesnois (France). The species was found in Southern Transcaucasia (praesulcata Zone of the standard conodont biozonation) (Rzhonsnitskaia \& Mamedov, 1988, p. 132-133, fig. 2). Plodowski \& Selanci (1990, p. 243) signal "Eobrachythyris strunianus " in Turkey (Anatolia) in the upper part of the Naltas Member in the Ziyarettepe Formation, Upper Famennian, corresponding to the Upper costatus Zone of the conodont biozonation (Plodowski \& Kononova, 1994, p. 21). P. struniana is present in the Upper Famennian (Etroeungt Zone) in Afghanistan, Axial Zone (Robat-e-Paï, Ghouk) and northern part of the Central Mountains (Brice, 1971; Brice \& Mistiaen, 1985). Its presence in Algeria (Legrand, 1968 , tab. 6, p. 280-281) needs to be confirmed

Prospira sp. cf. Prospira struniana (GOSSELET, 1879) Figs 8.6a-c

Material : As 112: $1 \mathrm{sp}$.

Discussion: Moroccan material has yielded one less transverse specimen, more inflated than Prospira struniana with more developed sulcus and fold and only twelve lateral costae. This form is reminiscent of one Afghan specimen that DB assigned to Prospira struniana (Brice, 1971, p. 3 GK 000157 = GFCL 3207). In our opinion, this specimen probably belongs to another species of Prospira which cannot be presently defined due to lack of sufficient material.

Figure 8. Figs 8. 1-5; 8.7; 8.9-12 Prospira struniana (GOSSELET, 1879)

1a-c. GFCL 3146. Ventral valve, a: exterior view, b: interior view, c: posterior view.

2a-c. GFCL 3147. Complete specimen, a: ventral view, b: dorsal view, c: posterior view.

3a-b. GFCL 3148. Complete specimen, a: dorsal view, b: posterior view.

4. GFCL 3149. Ventral view.

5. GFCL 3150. Ventral view.

7. GFCL 3151. Ventral view.

9a-b GFCL 3152. 9a: ventral view, 9b: dorsal view of another specimen.

10, 11, 12. Collection P. Morzadec from Jbel Tazout. 10: dorsal view, 11 \& 12 ventral views.

Figure 8. 6a-c. Prospira sp. GFCL 4642. a, b, c: ventral, dorsal, posterior views.

Figure 8.8. Dmitria seminoi (VERNEUIL, 1850). GFCL 4643. Micro-ornament. 


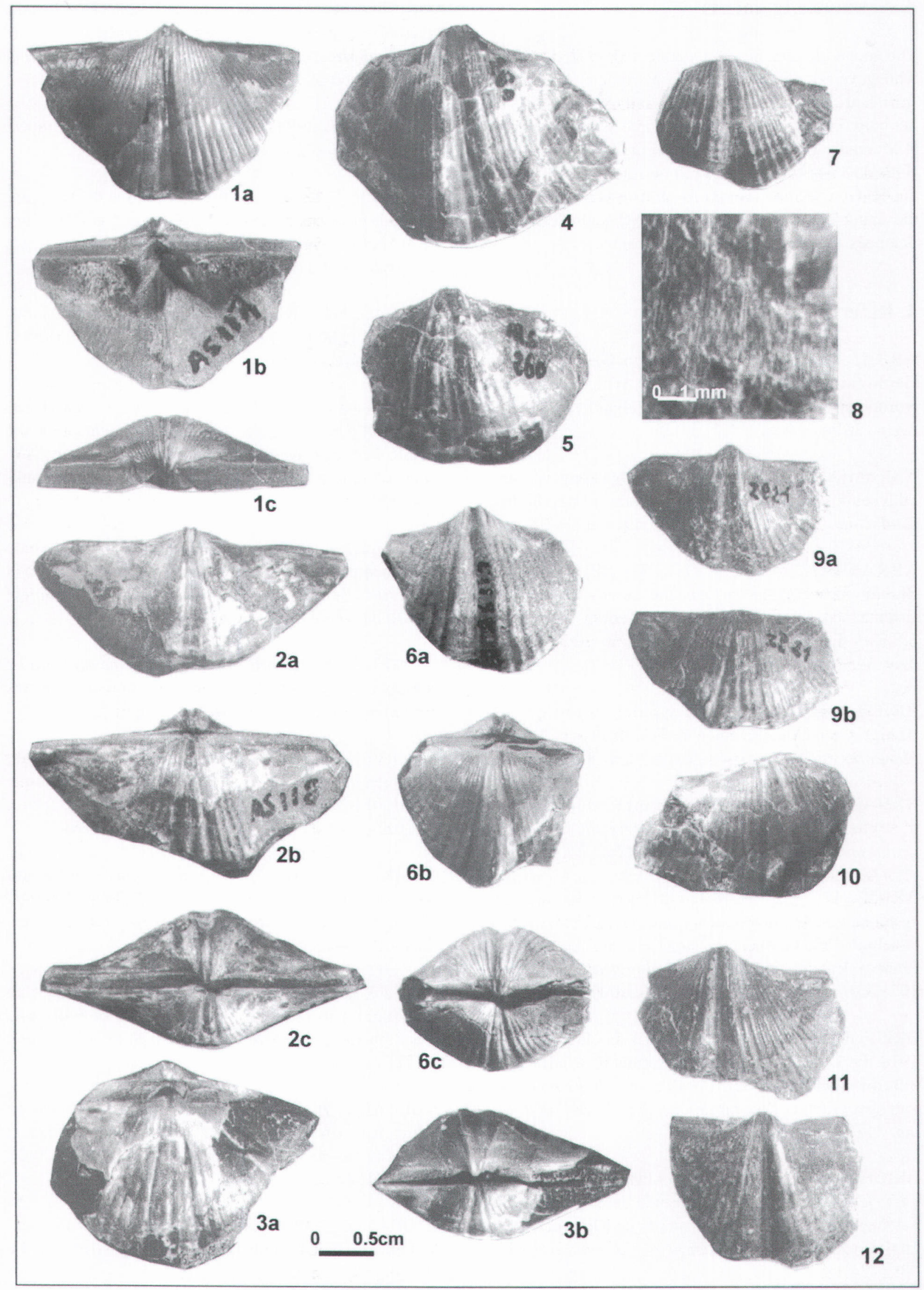




\section{Acknowledgements}

The second author is greatly indebted to H. Hollard $†$, who gave her the study of his Moroccan Famennian spiriferid brachiopods collections and to Dr. J. Drot $†$ for her help concerning this material. The authors thank Dr. P. Morzadec (Rennes) for the loan of collections, Dr. A. Balinski (Warszawa), Dr. J. Godefroid (Bruxelles) and Dr. R. Gourvennec (Brest) for constructive reviews of the manuscript and Mrs J. Spencer (Faculté Libre des Sciences, Lille) for correcting the language.

\section{References}

ABICH, H., 1858. Vergleichende Grundzuge der Geologie der Kaukasus wie der Armenischen und Nordpersischen Gebirge. Mémoire Académie des Sciences, St-Petersbourg, 7: 523-525.

ABRAMIAN, M.S., 1957. Brakhiopody verkhnefamenskikh i etrenskikh otlojenii iougo-zapadnoi Armenii. Inst. Geol. Nauk. Ak. Nauk. Arm. S.S.R., Erevan: 38-93.

ABRAMIAN, M.S., 1974. Tip Brachiopoda. Brakhiopody : 48-84 in Opisanie faouny. Devonskaia sistema, : 31-64 in Atlas iskopaemoi faouny Armianskoi S.S.R., V.T. Akopian (Ed.). Inst. Geol. Naouk. Ak. Naouk. Arm. S.S. R., Erevan.

BRICE, D., 1971. Etude paléontologique et stratigraphique du Dévonien de l'Afghanistan. Notes et Mémoires du Moyen Orient, Paris, Mém. 11: 1-364.

BRICE, D., 1977. Biostratigraphie du Dévonien d'Afghanistan. Mémoire hors série de la Société géologique de France, Paris, 8: 267-276.

BRICE, D., 1997. Clarification sur la position systématique de Spirifer strunianus GOSSELET, 1879, Brachiopode du Famennien supérieur de l'Avesnois (N. France). Emendation du genre Eobrachythyris BRICE, 1971. Geobios, Lyon, Mémoire spécial 20: 61-67.

BRICE, D., JENNY, J., STAMPFLI, G. \& BIGEY, F., 1978. Le Dévonien de l'Elbourz oriental: stratigraphie, paléontologie (Brachiopodes et Bryozoaires), Paléogéographie. Rivista italiana di paleontologia, Milan, 84 (1): 1-56.

BRICE, D., LAFUSTE, J., DE LAPPARENT, A.F., PILLET, J. \& YASSINI, I., 1974. Etude de deux gisements paléozoïques (Silurien et Dévonien) de l'Elbourz oriental (Iran). Annales de la Société géologique du Nord, Lille, 93: 177-218.
CARTER, J.L., JOHNSON, J.G., GOURVENNEC, R. $\&$ HOU Hong-Fei, 1994. A revised classification of the Spiriferid Brachiopods. Annals of Carnegie Museum, Pittsburgh, 63 (4): 327-374.

DAGNELIE P., 1998. Statistique théorique et appliquée. Tome 2. De Boeck Universities, Paris-Bruxelles.

DEHEE, R., 1929. Description de la faune d'Etroeungt. Faune de passage du Dévonien au Carbonifère. Mémoires de la Société géologique de France, Paris, nouv.série, 5 , 11: 1-62.

DROT, J., 1964. Rhynchonelloidea et Spiriferoidea silurodévoniens du Maroc Présaharien. Notes et Mémoires Service géologique du Maroc, Rabat, 178: 1-237.

GARCIA-ALCALDE, J.L. \& MENENDEZ-ALVAREZ, J.R., 1988. The Devonian-Carboniferous Boundary in the Asturo-Leonaise Domain (Cantabrian Mountains, NW Spain). Courier Forschungsinstitut Senckenberg, Frankfurt, 100: 21-37.

GOSSELET, J., 1879. Nouveaux documents pour l'étude du Famennien. Tranchée de chemin de fer entre Féron et Sémeries: Schistes de Sains. Annales de la Société géologique du Nord, Lille, 6: 389-399.

GOSSELET, J., 1880. Esquisse géologique du Nord de la France et des contrées voisines. $1^{\text {er }}$ fascicule. Terrains primaires, Imprimerie Six, 167 p., Lille.

GOURVENNEC, R., 1989. Brachiopodes Spiriferida du Dévonien inférieur du Massif Armoricain. Systématique - Paléobiologie - Evolution - Biostratigraphie. Biostratigraphie du Paléozoïque, Brest, 9: 1-281.

GREINER, H., 1957. "Spirifer disjunctus" : its evolution and paleoecology in the Catskill Delta. Peabody Museum of Natural History Yale University Bulletin, New Haven, 11: 1-75.

HALL, J. \& CLARKE, J.M., 1894, Palaeontology : an introduction to the study of the genera of Paleozoic Brachiopoda. Geological Survey of the State of New York, $8,(2): 177-215,368-374$.

HOLLARD, H., 1981. Tableaux de corrélations du Silurien et du Dévonien de l'Anti-Atlas. Notes et Mémoires Service géologique du Maroc, Rabat, 308, (42), 23, 5 tableaux.

LEGRAND, P., 1968. Le Dévonien du Sahara algérien. In Oswald (Ed.), International Symposium on the Devonian system, Calgary, 1: 245-284. 
MISTIAEN, B., 1985. Phénomènes récifaux dans le Dévonien d'Afghanistan (Montagnes centrales). Analyse et systématique des Stromatopores. Publication Société Géologique du Nord, Lille, 11 (1): 1-381.

MURCHISON, R.I., 1840. Sur les roches dévoniennes, type particulier de l'Old Red Sandstone des géologues anglais qui se trouvent dans le Boulonnais et les pays limitrophes. Bulletin de la Société géologique de France, Paris, 1 ère série, 11: 229- 256.

MURCHISON, R.I., VERNEUIL, E. de, \& KEYSERLING, A., 1845. Géologie de la Russie d'Europe et des Montagnes de l'Oural, II, Paléontologie: 512 p.

NALIVKIN, D.V., 1937. Brachiopoda of the Upper and Middle Devonian and Lower Carboniferous of NE Kazakhstan. Transactions of the Central Geological and Prospecting Institute, Moscow, 99: 1-200.

PLODOWSKI, G. \& KONONOVA, L., 1994. Dichospirifer BRICE 1970, eine Leit-Gattung im höchsten Oberdevon. Courier Forschungsinstitut Senckenberg, Frankfurt, 169: 17-27.

PLODOWSKI, G. \& SELANCI, A., 1990. Devon/Karbon Grenze in Anatolien. Courier Forschungsinstitut Senckenberg, Frankfurt, 127: 238-249.

REED, F.R.C., 1922. Devonian fossils from Chitral and the Pamirs. Memoirs of the Geological Survey of India, Palaeontologica Indica, Calcutta, n.s., 6, (2): 1-134.
RZHONSNITSKAIA, M.A., 1988 (in russian). The Brachiopoda of the Devonian/Carboniferous Boundary deposits on the USSR territory. In Sokolov et al. (Eds), The Devonian/Carboniferous Boundary at the territory of the USSR, Minsk "Nauka I Technica”, 7: 262-270.

RZHONSNITSKAIA, M.A. \& MAMEDOV, A.B., 1988, (in russian). The Devonian/Carboniferous Boundary deposits in the Southern Transcaucasus. In Sokolov et al. (Eds), The Devonian Carboniferous Boundary at the territory of the USSR, Minsk "Nauka i Technika", 8: 124-136.

VANDERCAMMEN, A., 1956. Révision de Spinocyrtia struniana (GOSSELET 1879) (Spiriferidae). Bulletin de l'Institut royal des Sciences naturelles de Belgique, Bruxelles, 32, 59: 1-9.

VANDERCAMMEN, A, 1967. Les Spiriferida de la Collection Hommaire de HELL. Bulletin de l'Institut royal des Sciences naturelles de Belgique, Bruxelles, 43, 17: 1-20.

VISQUENEL, A., 1850. Notice sur la collection de roches recueillies en Asie par feu Hommaire de Hell et sur les divers travaux exécutés pendant le cours de son voyage. Bulletin de la Société géologique de France, Paris, 1 ère série, 7: 491- 514.

Manuscript received on 29.11.2000 and accepted for publication on 26.3.2001 